\title{
FAKTOR-FAKTOR PREDIKTOR INVESTMENT OPPORTUNITY SET DAN FIRM VALUE PADA PERUSAHAAN PROPERTYDAN REAL ESTATE YANG TERDAFTAR DI BEI
}

\author{
Rita Amelinda \\ Program Studi Magister Manajemen Universitas Tarumanagara \\ ritaamelinda@gmail.com \\ Dr. Indra Widjaja \\ Program Studi Magister Manajemen Universitas Tarumanagara
}

\begin{abstract}
Great integration and similar point of view between stakeholders are essential to build an optimal firm value. As alongwith firm value, most of investor also view rate of return in their investment. Therefore, investment opportunity set could also become a mediator to optimize firm value. Recently, in a crisis and financial distress condition, these two main variables lead to dilemma for some company such. This study aims to find out about the factors which predict the firm value and investment opportunity set. The sample of this research consist on 39 companies in property and real estate industry sector which listing in Indonesia Stock Exchange (IDX) between 2012 until 2016 period. This research used panel regression analysis with fixed effect method to test their hypothesis. The conclusion of this study indicate that simultaneously, leverage, financial risk, free cash flow, institutional ownership, and working capital affect the firm value significantly. While, partially, only leverage, free cash flow, and working capital which affect the firm value significantly. On the other hand, investment opportunity set has only perfectly mediating between financial risk and institutional ownership to firm value and partially mediating leverage to firm value.
\end{abstract}

Keywords : Firm value, Investment opportunity set, Leverage, Financial risk, Institutional ownership, Free cash flow, Working capital

\section{PENDAHULUAN}

Firm value dan investment opportunity set merupakan salah satu pertimbangan investor dalam menilai prospek sebuah perusahaan. Untuk mencapai firm value itu sendiri, diperlukan beragam fungsi dan kebijakan dalam menunjang kegiatan operasional dan investasi yang ada. Ameer (2012) menyatakan bahwa alokasi sebuah perusahaan dalam mengelola asetnya merupakan faktor fundamental dalam meningkatkan pertumbuhan perusahaan di masa depan yang akan secara searah mempengaruhi mengoptimalkan kesejahteraan pemegang saham. Dari sudut pandang investor sendiri, tinggi-rendahnya firm value akan tercermin melalui harga pasar saham sebuah perusahaan tersebut (Walker, 2000).

Integrasi stakeholder sangat penting di tengah kondisi persaingan yang ketat dalam rangka mewujudkan firm value yang optimal bagi kesejahteraan pemegang saham. Pentingnya firm value ini menjadi sebuah dilema bagi perusahaan dalam kondisi perekonomian yang krusial. Krisis perekonomian global yang terjadi pada 2008 membuat firm value dan tingkat investasi berfluktuasi secara signifikan. Beragam sektor industri mengalami penurunan indeks saham. Hal ini dirasakan secara perekonomian hingga kini. Beragam perusahaan melakukan downsizing atau bahkan menutup usahanya. Berdasarkan data di Bursa Efek Indonesia, indeks harga saham yang merefleksikan firm value bagi investor memiliki tren yang menurun hingga tahun 2015. Hal ini tentu membuat perusahaan sulit terhindar dari financial distress, kondisi keuangan yang memburuk ini membuat 
perusahaan sulit untuk bertahan pada posisi pasarnya. Tingkat financial distress yang tinggi tentu akan membuat investor enggan untuk melakukan investasi dalam jumlah besar dan berisiko pada kondisi keuangan dan perekonomian tersebut. Dengan demikian, tingginya financial distress membuat perusahaan harus lebih selektif dalam menganalisis dan menentukan proporsi sumber pendanaan yang digunakan dan alokasi sumber daya yang ada dengan mempertimbangkan risiko dan meminimalisir konflik keagenan yang mungkin timbul.

Dengan demikian, penelitian ini dilakukan dengan tujuan untuk mengidentifikasi signifikansi faktor-faktor yang memprediksi investment opportunity set dan firm value pada sektor property di tengah permasalahan ekonomi yang sedang terjadi pada tahun 2008 hingga saat ini.

\section{TINJAUAN PUSTAKA}

Investment opportunity set (IOS) pertama kali diperkenalkan oleh Myers (1997). Menurutnya, pada dasarnya investment opportunity set merupakan kombinasi antara nilai assets in place dengan pilihan investasi di masa depan.

Firm value menurut Brigham \& Ehrhardt (2011) adalah suatu ukuran maksimisasi kekayaan pemegang saham yang dicerminkan melalui harga saham perusahaan di masa depan sampai tidak terhingga yang didiskontokan.

Leverage mengacu pada efek yang dimiliki biaya tetap terhadap tingkat pengembalian yang diinginkan oleh pemegang saham, semakin tinggi leverage akan menghasilkan tingkat pengembalian yang semakin tinggi, tetapi tidak stabil (Gitman \& Zutter, 2012:508). Crutchley \& Hansen (1989) menyatakan bahwa peningkatan leverage akan meminimalkan konflik antara pemegang saham dan manajemen melalui monitoring yang dilakukan kreditor. Utang juga akan mengurangi arus kas yang berlebih di dalam perusahaan sehingga dapat mengurangi kemungkinan pemborosan yang dilakukan oleh manajemen. Hal ini didukung oleh Reyna \& Encalda (2012) yang membuktikan bahwa struktur modal seperti utang akan berpengaruh terhadap kinerja dan firm value dengan implikasi yang positif.

Financial risk merupakan tingkat bagaimana sekuritas dengan tingkat pengembalian tetap (utang dan saham preferen) digunakan dalam mengukur modal perusahaan (Brigham \& Houston, 2012). Gitman \& Zutter (2012) mengungkapkan bahwa financial risk berguna untuk mengukur risiko finansial dan mengendalikan risiko yang ada dari kegiatan finansial. Financial risk dalam hal ini diukur dengan pendekatan degree of financial risk mengukur sensitiviatas earnings per share yang diterima oleh pemegang saham suatu perusahaan atas fluktuasi laba operasional yang didapatkan (Adenugba, Ige, \& Kesinro, 2016). Pada dasarnya financial risk digunakan untuk meningkatkan tingkat pengembalian pemegang saham dalam kondisi yang menguntungkan. Dengan mengadopsi konsep trade off theory yang menggunakan leverage sebagai sumber eksternal modal dalam operasional perusahaan membuat variabel ini memiliki dampak dalam peningkatan earnings per share bagi pemegang saham maupun dampak risiko keuangan yang berpeluang untuk terjadi pada batas tertentu (Ojo, 2012).

Free cash flow (FCF) menurut Pradana \& Sanjaya (2014) bermanfaat untuk dapat membandingkan FCF antar perusahaan pada periode yang berbeda digunakan rasio FCF terhadap aset. Hal yang serupa dengan Jensen diungkapkan oleh Ross, et. al. (2008), free cash flow merupakan peluang atas kelebihan kas yang didiskontokan pada waktu tidak terhingga yang diperlukan untuk mendanai investasi dan proyek yang memiliki nilai net present value positif. Ghodrati \& Hashemi (2014) menyatakan bahwa free cash flow menjadi pengukur kinerja perusahaan yang dicerminkan melalui kas yang tersedia untuk perusahaan setelah membayar beban yang dibutuhkan dalam memelihara dan mengembangkan asetnya. 
Institutional ownership menurut Manzaneque et. al. (2015:6), adalah kepemilikan saham yang dimiliki oleh pemegang saham institusional yang memiliki saham sebanyak tiga persen atau lebih. Tindakan monitoring dapat mendorong manajer untuk lebih memfokuskan perhatiannya terhadap kinerja perusahaan sehingga manajer akan bersikap hati-hati dalam menjalankan usahanya dan akan memilih peluang investasi yang positif. Semakin tingginya pengawasan serta menurunnya biaya keagenan menyebabkan semakin efektif dan efisien perusahaan sehingga firm value akan cenderung meningkat.

Working capital atau modal kerja adalah indikator penilaian kinerja suatu perusahaan dalam melakukan aktivitas operasionalnya secara efektif dan efisien. (Ross, et.al., 2008). Menurut Brigham dan Ehrhardt (2011), modal kerja lebih dikenal dengan modal kerja lebih dikenal dengan gross working capital yang terdiri dari aset lancar yang digunakan dalam aktivitas operasi perusahaan. Perusahaan yang mengelola working capital-nya dengan efisien akan membuat dasar yang kuat dalam mendukung strategi perusahaan secara menyeluruh dalam mencapai tujuan perusahaan yaitu menciptakan firm value (Makori \& Ambrose, 2013).

Penelitian Hidayah (2014) pada 30 perusahaan propertydan real estate yang terdaftar di Bursa Efek Indonesia periode 2010 - 2012 menemukan bahwa kepemilikan manajerial, profitabilitas (ROA), dan ukuran perusahaan memiliki pengaruh positif dan signifikan terhadap firm value sementara leverage memiliki pengaruh negatif tetapi kurang signifikan. Lalu, Ameer (2012) membuktikan pada penelitiannya bahwa terdapat pengaruh positif dan signifikan antara cash holdings dan struktur kepemilikan terhadap firm value. Penelitian ini dilakukan pada 389 perusahaan sektor non financial periode 1995-2005. Kemudian, Hachiya (2005) dalam penelitiannya pada 5.382 perusahaan non-financial yang terdaftar di Tokyo Stock Exhange periode 1989-2002 membuktikan bahwa terdapat pengaruh secara signifikan positif antara sales growth, sales volatility, $\mathrm{R} \& \mathrm{D}$, cash flow, dividend, leverage terhadap firm value sementara pengaruh yang signifikan namun negatif antara net working capital, size, capital spending terhadap firm value. Sementara itu, Ramadan (2015) telah meneliti 1.082 perusahaan peride 2000-2013 pada perusahaan yang terdaftar di ASE (Amman Stock Exchange). Pada penelitian ini ditemukan pengaruh signifikan positif signifikan antara firm size dan sales growth terhadap firm value. Sementara long term debt memiliki pengaruh negatif signifikan terhadap firm value dan asset structure berpengaruh positif tetapi kurang signifikan terhadap firm value.

\section{HIPOTESIS}

Hipotesis 1: terdapat pengaruh signifikan antara leverage, financial risk, free cash flow, institutional ownership, dan working capital turnover terhadap firm value perusahaan sektor propertydan real estate yang terdaftar di Bursa Efek Indonesia periode 2012-2016

Hipotesis 2: nvestment opportunity set memediasi secara signifikan pengaruh antara (a) leverage, (b) financial risk, (c) free cash flow, (d) institutional ownership, dan (e)working capital turnover terhadap firm value secara bersama-sama mempengaruhi pada perusahaan sektor property dan real estate yang terdaftar di Bursa Efek Indonesia periode 2012-2016.

Hipotesis 3: terdapat pengaruh signifikan leverage terhadap firm value perusahaan sektor property dan real estate yang terdaftar di Bursa Efek Indonesia periode 2012-2016.

Hipotesis 4: terdapat pengaruh signifikan antara Financial risk terhadap firm value perusahaan sektor property dan real estate yang terdaftar di Bursa Efek Indonesia periode 2012-2016.

Hipotesis 5: terdapat pengaruh signifikan antara Free cash flow terhadap firm value perusahaan sektor property dan real estate yang terdaftar di Bursa Efek Indonesia periode 2012-2016. 
Hipotesis 6: terdapat pengaruh signifikan antara Institutional ownership terhadap firm value perusahaan sektor property dan real estate yang terdaftar di Bursa Efek Indonesia periode 2012-2016.

Hipotesis 7: terdapat pengaruh signifikan antara working capital turnover terhadap firm value perusahaan sektor property dan real estate yang terdaftar di Bursa Efek Indonesia periode 2012-2016.

\section{METODOLOGI PENELITIAN}

Populasi dalam penelitian ini adalah perusahaan-perusahaan sektor property dan real estate yang telah go public di Bursa Efek Indonesia periode 2012-2016. Metode pemilihan dilakukan dengan cara sensus. Mengingat seluruh populasi digunakan dalam penelitian ini, maka tidak ada pemilihan sampel. Terdapat 39 daftar perusahaan industri sektor propertydan real estate yang telah go public di Bursa Efek Indonesia dengan data tahun 2012-2016 yang digunakan dalam penelitian ini. Penelitian ini melakukan pengolahan 195 data observasi dengagn mengunakan persamaan regresi linear berganda dengan metode Ordinary Least Square melalui program Eviews 9.

\section{OPERASIONALISASI VARIABEL}

Berikut merupakan tabulasi rangkuman perolehan data dari setiap variabel dalam penelitian ini:

\begin{tabular}{|c|c|}
\hline $\begin{array}{r}\text { Variabel } \\
\end{array}$ & Indikator \\
\hline Investment opportunity set & $\begin{array}{l}\text { CAPMVA } \\
=\frac{\left(B V \text { Fixed } \text { Asset }_{t}-\text { Fixed Asset }_{t-1}\right)}{T A-T E+(O S \times \text { Clossing Price }))}\end{array}$ \\
\hline Firm value & PBV $=\frac{\text { Market Price }}{\text { Book Value of Common Stock }}$ \\
\hline Leverage & Debt to Total Equity $=\frac{\text { Total Debt }}{\text { Total Equity }}$ \\
\hline Financial risk & $D F L=\frac{E B I T}{E B T-\frac{\text { Div.of } p / s}{1-\operatorname{tax}}}$ \\
\hline Free cash flow & $\begin{array}{l}F C F \\
=\frac{(O C F-C A P E X-\text { Working Capital })}{\text { Total Aset }}\end{array}$ \\
\hline Institutional ownership & $\begin{array}{l}\text { Institutional Ownership } \\
=\frac{\text { Jumlah saham yang dimiliki institusi }}{\text { Jumlah saham beredar }}\end{array}$ \\
\hline Working capital & WCTO $=\frac{\text { Sales }}{\text { Working Capital }}$ \\
\hline
\end{tabular}

\section{HASIL PENGUJIAN}

Analisis regresi berganda yang telah dilakukan pada penelitian ini menghahsilkan model regresi dengan leverage, financial risk, free cash flow, institutional ownership, dan working capital sebagai variabel independen yang memprediksi tingkat firm value. Berikut merupakan hasilnya:

\section{FValue $=-0.127014-1.154352$ DER + 0.035476 DFL -1.627183 FCF - 0.072375 INST + 0.361039 WCTO Ringkasan Signifikansi Prediktor dalam Pengujian Hipotesis}




\begin{tabular}{|c|c|c|c|}
\hline Variabel & Hipotesis/Teori & Koefisien & Prob. \\
\hline C & & -0.127014 & 0.7737 \\
\hline DER & + & -1.154352 & $0.0147 * *$ \\
\hline DFL & + & 0.035476 & 0.0844 \\
\hline FCF & - & -1.627183 & $0.0214 * *$ \\
\hline INST & + & -0.072375 & 0.9501 \\
\hline WCTO & + & 0.361039 & $0.0000^{* * *}$ \\
\hline \multicolumn{2}{|c|}{$\mathrm{N}$} & \multicolumn{2}{|c|}{0.078075} \\
\hline $\mathrm{R}^{2}$ & \multicolumn{2}{|c|}{$0.008479^{*} * *$} \\
\hline \multicolumn{2}{|c|}{ Prob (F-Stat) }
\end{tabular}

Berdasarkan model di atas, dapat disimpulkan bahwa leverage berkontribusi secara negatif sebesar 1.154352 satuan terhadap firm value. Sementara fianncial risk akan berkontribusi secara positif sebesar 0.035476 satuan terhadap firm value. Kemudian, free cash flow akan berkontribusi secara negatif sebesar 1.627183 satuan terhadap firm value. Selanjutnya, institutional ownership akan berkontribusi secara negatif juga sebesar 0.072375 satuan terhadap firm value. Namun, working capital akan berkontribusi secara positif sebesar 0.36109 satuan terhadap firm value.

Ringkasan Model untuk Pengujian Mediasi

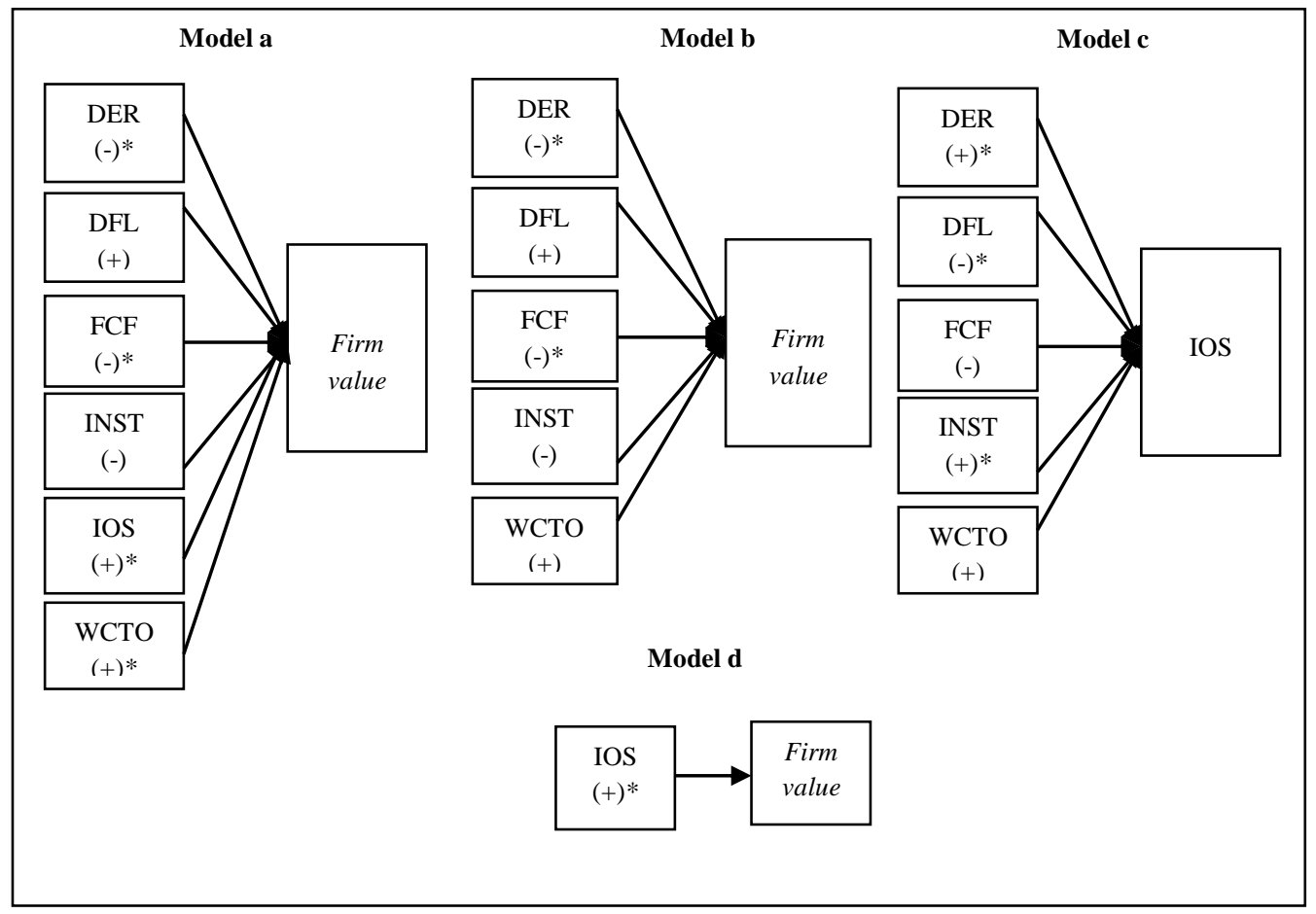

Berdasarkan tabulasi ringkasan signifikansi prediktor dalam pengujian hipotesis dapat disimpulkan bahwa secara bersama - sama kelima variabel berpengaruh positif dan signifikan terhadap firm value dengan tingkat keyakinan 95\%. Kelima variabel independen ini diteliti dapat mengidentifikasi tingkat firm value dengan kontribusi sebesar 7,8\%. Sementara secara parsial, hanya variabel leverage, free cash flow dan working capital yang dapat menjadi prediktor yang signifikan atas firm value dengan tingkat keyakinan $95 \%$. Sementara, financial risk dan investment opportunity set mempengaruhi firm value secara tidak signifikan dengan tingkat keyakinan 95\%. Selanjutnya, berdasarkan hasil penenlitian, investment opportunity set tidak memediasi secara signifikan pengaruh antara leverage, financial risk, free cash flow, institutional ownership, investment opportunity set, dan 
working capital terhadap firm value. Hal ini dibuktikan dari kombinasi hasil model pertama, kedua, dan ketiga. Berikut pada gambar di bawah merupakan hasil kombinasi yang membuktikan investment opportunity set sebagai mediasi sempurna antara financial risk dan institutional ownership sebagai prediktor firm value. Selain itu, investment opportunity set juga terbukti memediasi secara parsial pengaruh antara leverage terhadap firm value.

\section{PEMBAHASAN}

Berdasarkan hasil pengujian yang telah diteliti, dapat disimpulkan bahwa pengendalian yang selektif terhadap penentuan beberapa faktor pendanaan dan pengalokasian sumber daya dapat meningkatkan investment opportunity set dan firm value. Pada sisi lain, hasil penelitian ini membuktikan bahwa perubahan tingkat hutang, risiko keuangan, dan kepemilikan dapat dikategorikan sebagai indikator pemberi sinyal peluang investasi yang memprediksi perubahan firm value. Sementara free cash flow dan working capital turnover tidak memiliki kontribusi dalam pemberian sinyal investasi yang dapat meningkatkan firm value. Sementara itu, tingkat leverage yang tinggi akan meminimalisir rmasalah keagenan dan mendukung peningkatan arus informasi yang lebih baik antara manajer dan pemegang saham melalui campur tangan kreditor. Akan tetapi pada sisi lain, penggunaan leverage yang terindikasi dengan tingkat hutang yang tinggi dapat menjadi bahaya bagi perusahaan apabila kondisi perekonomiannya sedang tidak stabil. Tentunya, kondisi ini dapat memicu perusahaan ke dalam kondisi financial distress yang dapat menurunkan firm value. Hal inilah yang membuat leverage secara negatif dan signifikan mempengaruhi firm value. Sementara dari pendekatan variabel financial risk, peningkatan risiko secara tidak langsung dapat meningkatkan peluang dalam memperoleh tingkat pengembalian atau return untuk pemegang saham dalam kondisi yang berprospek baik. Sesuai penelitian Ojo (2012) bahwa peningkatan risiko dari penggunaan hutang pada konsep trade off theory dapat memberikan variabilitas peningkatan laba per saham pada proyeksi rencana investasi yang menguntungkan di masa depan. Selanjutnya, serupa dengan penelitian Ghodrati \& Hashemi (2014) bahwa free cash flow menghasilkan opportunistic behavior yang dapat memberikan pengaruh negatif terhadap firm value. Makna dari hasil temuan tersebut adalah arus kas bebas yang berlebih terlalu banyak dapat menyebabkan penyalahgunaan arus kas untuk kepentingan pribadi atau kepentingan pengembangan yang tidak terlalu signifikan meningkatkan firm value. Kemudian, insititutional ownership berupaya untuk memfokuskan perusahaan secara hati-hati menjalankan operasionalnya dan memanfaatkan peluang yang tepat dan positif. Temuan dalam penelitian ini tidak sesuai dengan hipotesis dan teori yang dinyatakan tersebut karena proporsi institutional ownership yang mayoritas terlalu besar berkisar antara 80 hingga 90 persen. Institutional ownership yang terlalu tinggi dapat berdampak buruk bagi perusahaan karena keputusan yang diambil dapat hanya menguntungkan institusi tersebut secara pribadi tanpa mementinkan kepentingan umum dan tujuan dari perusahaan tersebut. Selain itu, temuan dari penelitian ini juga membuktikan bahwa working capital turnover yang tinggi akan mengindikasikan keefektivitasan dan keefisienan dalam menjalankan operasional dan mengelola aset perusahaan. Dengan demikian hal ini akan berdampak juga pada firm value yang meningkat secara searah. Hal ini serupa dengan dengan penelitian Makori \& Ambrose (2013), Hachiya (2005), dan Wasiuzzaman (2014).

\section{DAFTAR PUSTAKA}

Adenugba, Ige, dan Kensiro. (2016). Financial risk and Firms' Value: A Study of Selected Firms in Nigeria. European Journal of Research and Reflection in Management Sciences. 4(1). 
Ameer, Rashid. (2012). Impact of Cash Holdings and Ownership Concentration on Firm Valuation: Empirical Evidence from Australia. Review of Accounting and Finance Vol 11 (4).

Brigham, E.F., Ehrhardt, M.C. (2011). Financial Management : Theory and Practice. Thirteenth edition. Cengage Learning. dan Houston, Joel. (2010). Dasar - Dasar Manajemen Keuangan : Assetials Of Financial Management. Jakarta: Salemba Empat.

Crutchley, C.E., dan Hansen, R.S. (1989). A Test of The Agency Theory of Managerial Ownership, Corporate Leverage, and Corporate Dividends. Financial Management.Vol.18(4).

Ghodrati, Hassan, dan Abbas Hashemi. (2014). A Study on Relationship among Free cash flow, Firm Value, and Investors' Cautiousness: Evidence from Tehran Stock Exchange. Management Science Letters.

Gitman J. Lawrence dan Chad J. Zutter. (2012). Principle of Managerial Finance $13^{\text {th }}$ edition. England: Pearson

Hachiya, Qi Luo Toyohiko. (2005). Bank Relations, Cash Goldings, and Firm Value: Evidence from Japan. Management Research News Vol 28 (4).

Hidayah, Nurul. (2014). The Effect of Company Characteristic toward Firm Value in The Properti and Real estate Company in Indonesia Stock Exchange. International Journal of Business, Economics, and Law. Vol 5 (1).

Makori, Daniel Mogaka dan Ambrose Jagongo. (2013). Working capital Management and Firm Profitability: Empirical Evidence from Manufacturing and Construction Firms Listed on Nairobi Securities Exchange. International Journal of Accounting and Taxation, 1(1)

Manzaneque, M., Priego, A.M., \& Merinho, E. (2015). Corporate Governance Effect on Financial Distress Likelihood : Evidence from Spain. Spanish Accounting Review.

Myers, S. (1977). Determinants of Corporate Borrowing. Journal Financial Economics, 5:147-175.

Ojo, Akinmulegun. (2012). The Effect of Financial Leverage on Corporate Performance of Some Selected Companies in Nigeria. Canadian Social Science Vol 8 (1)

Pradana, Salvatore. W.L. dan Sanjaya, I Putu Sugiartha. (2014). Pengaruh Probabilitas, Free cash flow, dan Investment opportunity set Terhadap Dividend Payout Ratio. SNA 17 Mataram Lombok.

Ramadan, Imad Zeyad (2015). Leverage and The Jordanian Firms' Value: Empirical Evidence. International Journal of Economics and Finance; Vol 7 (4).

Reyna-Encalada. (2012). Ownership Structure, Firm Value, and Investment opportunity sets: Evidence from Mexican Firm. Journal of Entrepreneurship, Management, and Innovation. Vol 8 (3).

Ross, Stephen A., et.al. (2008). Fundamental of Corporate Finance. New York. The McGraw Hill.

Wasiuzzaman, Shaista. (2014). Working capital and Firm Value in an Emerging Market. Journal of Managerial Finance Vol 11 (1).

Walker, M. Mark. (2000). Corporate Take Over, Strategic Objectives, and Acquiring Firm Shareholders Wealth". Financial Management, Winter: pp. 36-46. 


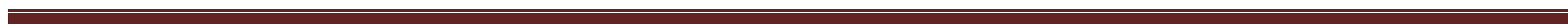
$\cdot$ 